\title{
Analysis of key variables controlling phosphorus removal in high rate oxidation ponds provided with clarifiers
}

\author{
Joan García ${ }^{1 *}$, Mariona Hernández-Mariné ${ }^{2}$ and Rafael Mujeriego ${ }^{1}$ \\ ${ }^{1}$ Secció d'Enginyeria Sanitària i Ambiental, Departament d'Enginyeria Hidràulica, Marítima i Ambiental, ETS Enginyers Camins, \\ Canals i Ports, Universitat Politècnica de Catalunya, c/ Gran Capità s/n, 08034 Barcelona \\ ${ }^{2}$ Laboratori de Botánica, Departament de Productes Naturals, Biologia Vegetal i Edafología, Facultat de Farmacia, \\ Universitat de Barcelona, c/ Joan XXIII s/n, 08028 Barcelona
}

\begin{abstract}
This study evaluates the influence of hydraulic retention time (HRT), solar radiation, and water temperature on phosphorus removal from two experimental high rate oxidation ponds (HROP) with clarifiers. Both HROPs were operated for a period of one year with different HRTs ( 3 to $10 \mathrm{~d}$ ), but under the same environmental conditions. Phosphorus species, phytoplankton biomass, solar cumulative radiation, water temperature and $\mathrm{pH}$ were measured once a week. Average total phosphorus removal (TP) was higher in the HROP operated with a higher HRT (43\%) than in that using a lower HRT (32\%). TP removal was due to dissolved reactive phosphorus (DRP) removal in the mixed liquor of the HROPs and transformation of DRP into particulate phosphorus (PP), with subsequent sedimentation of PP in the clarifiers. The influence of HRT on TP removal was due mainly to its control over DRP removal, which was observed to be more important in autumn and winter. The lowering of solar radiation and temperature in autumn and winter and their influence on DRP removal can barely be compensated by HRT to obtain a significant TP removal. This work indicates that DRP transformation into PP depends mainly on environmental factors through their mediated influence on $\mathrm{pH}$ and chemical precipitation.
\end{abstract}

\section{Introduction}

High rate oxidation pond (HROP) technology was introduced in California in the 1950s, with the aim of reducing the surface area required by conventional oxidation ponds (Oswald and Gotaas, 1957). HROPs are shallow ( 30 to $40 \mathrm{~cm}$ ) and operate by means of mechanical mixing. The energy applied to stir the mixed liquor promotes the growth of the phytoplankton and prevents its settling (Oswald, 1988a). HROPs need a lower mean hydraulic retention time (HRT) than oxidation ponds to treat the same wastewater flow (Abeliovich, 1986).

An HROP is an aerobic reactor where organic matter removal is achieved by a mutualistic relationship between bacteria and phytoplankton (Fallowfield and Garret, 1985; Abeliovich, 1986). The oxygen required for aerobic bacterial decomposition of organic matter is provided by photosynthesis, whereas carbon dioxide, ammonia and orthophosphate needed for phytoplankton growth are supplied from bacterial decomposition and from wastewater. The biomass produced in an HROP is due mainly to phytoplankton and should be subsequently separated to complete the wastewater treatment.

HROPs are usually designed for secondary treatment of wastewater; nevertheless, some removal of nutrients occurs (Oswald, 1988b). Nutrient uptake by phytoplankton and subsequent biomass separation causes removal (Nurdogan and Oswald, 1995; Cromar et al., 1996). In addition, phytoplankton photosynthetic activity raises $\mathrm{pH}$ in the pond, resulting in ammonia stripping and orthophosphate precipitation (Moutin et al., 1992). Phosphorus removal is concomitant with the biomass separation.

\footnotetext{
* To whom all correspondence should be addressed.

푠+34 93 4016464; fax: +34 93 4017357; e-mail: joan.garcia@upc.es Received 4 April 2001; accepted 9 November 2001.
}

Phosphorus in urban wastewater appears mainly as phosphates, which are classified as orthophosphates, polyphosphates and organically-bound phosphates (Standard Methods, 1995). During wastewater treatment in HROPs, complete hydrolysis of polyphosphates and decomposition of organically-bound phosphates results in the formation of orthophosphates (Nurdogan and Oswald, 1995). Most studies on the role of phytoplankton in orthophosphate removal point out that precipitation is more important than algal uptake (Shelef et al., 1982; Picot et al., 1991; Moutin et al., 1992; Nurdogan and Oswald, 1995). The high pH reached in HROPs and the supersaturation of orthophosphates, hydroxides, and carbonates with respect to calcium, magnesium and other metals promote chemical precipitation. In contrast with all of these studies, Mesplé et al. (1995) have estimated that most of the orthophosphate removal occurs by phytoplankton uptake.

In this paper the influence of environmental factors (HRT, solar radiation and water temperature) on phosphorus removal is studied when the HROPs are operated to reach secondary treatment standards. The influence of phytoplankton biomass and $\mathrm{pH}$ on phosphorus removal is also evaluated.

\section{Experimental}

Two experimental HROPs provided with low surface-loading rate clarifiers for phytoplankton separation were used. The experiments were carried out for a period of one year, from June 1993 to July 1994. The HROPs were constructed in PVC in a raceway form. Figure 1 shows the top and side view of the HROPs, showing size and shape, the location of the inlet and outlet and the six-paddle wheel mixer. Their surface area was $1.54 \mathrm{~m}^{2}$, the depth $0.3 \mathrm{~m}$ and the volume $0.47 \mathrm{~m}^{3}$. The turning speed of the paddle wheel in both HROPs was maintained at $4 \mathrm{r} / \mathrm{min}$, giving a mid-channel velocity of $9 \mathrm{~cm} / \mathrm{s}$. The mixed liquor from the HROPs passed on to the PVC clarifiers. Figure 2 shows a schematic diagram of the side and top 


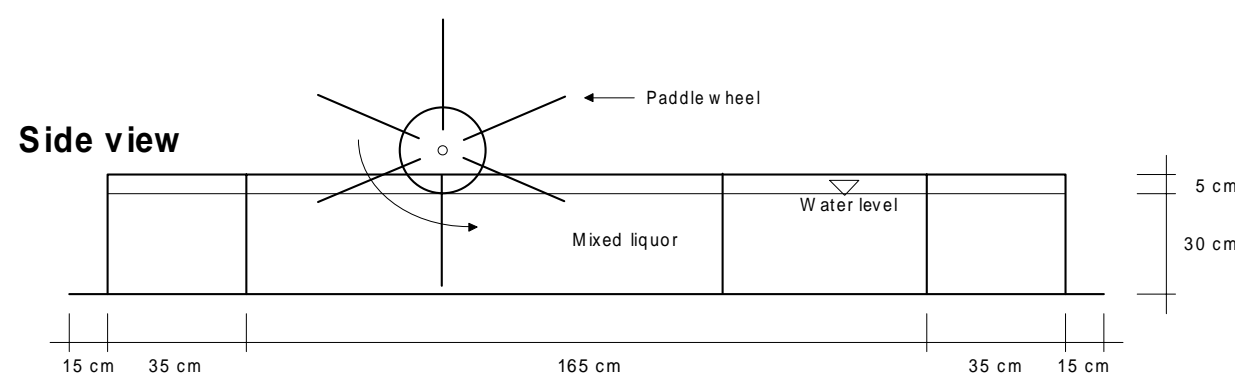

Top view

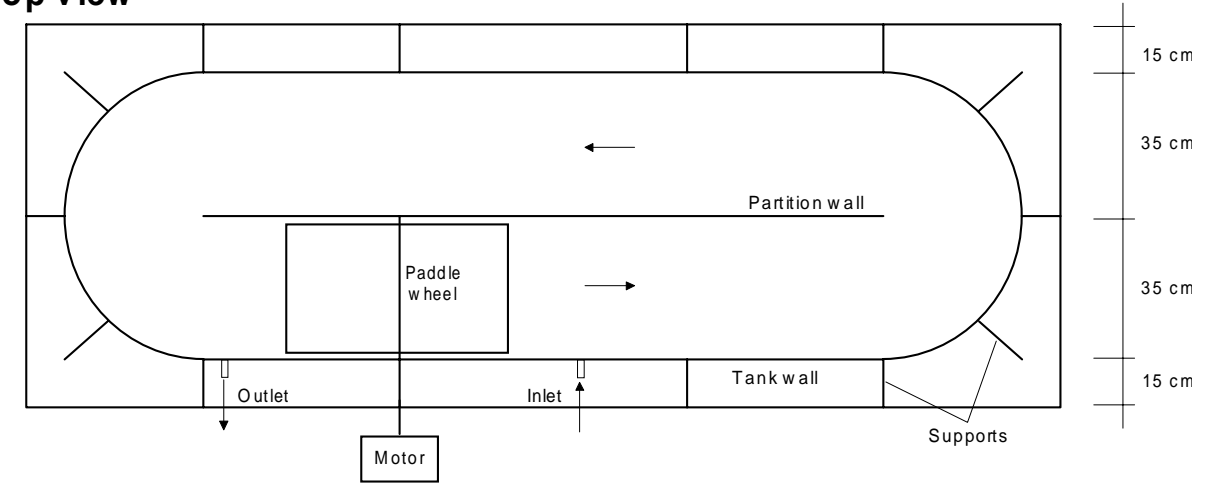

Figure 1

Diagram of the top and side view of the experimental HROPs
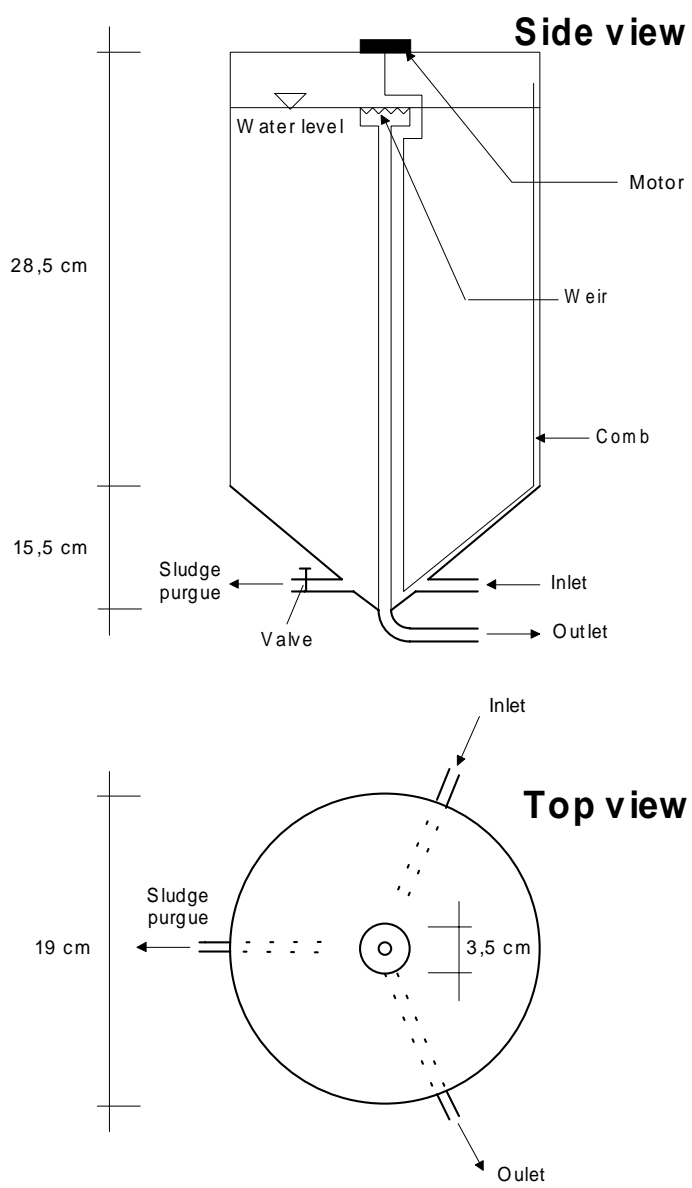

Figure 2

Diagram of the top and side view of the experimental clarifiers view of the clarifiers showing size and shape and the location of the inlet, the outlet and the phytoplankton sludge purge. An electric rotary comb was installed to prevent fouling inside the walls. The central toothed weir kept the depth of the HROP constant. The clarifiers surface area was $0.0255 \mathrm{~m}^{2}$

Municipal wastewater from the nearest street sewer was pumped to a $500 \ell$ tank (primary clarifier) once a day. After resting for 30 min, wastewater was added to a $500 \ell$ storage tank until full. From here, two peristaltic pumps fed the HROP continuously. In the storage tank, the resting wastewater not fed to the HROP and the new pumped water were mixed every day. Previous experiments demonstrated that influent HROPs quality did not show significant daily variations.

Table 1 shows the main physical and chemical characteristics of the influent. The average concentration of suspended solids and COD was lower than in typical raw wastewater due to the previous treatment in the primary clarifier and because of the residential nature of the area. The concentration of nitrogen and phosphorus was only affected slightly by the primary clarifier because they were present mainly as dissolved inorganic compounds. All of these characteristics caused a weak to medium influent wastewater according to the criteria of Metcalf and Eddy (1991), with a nontypical COD/N/P ratio.

Wastewater flow was used to control the HROPs mean HRT. The mean cellular retention time was identical to HRT because the system did not have biomass recycling. HRT was regulated according to the recommendations of Oswald $(1988 \mathrm{a} ; 1988 \mathrm{~b})$ and previous experiments which showed that an HRT ranging from 3 to $10 \mathrm{~d}$ in summer and winter respectively was enough to achieve secondary treatment and ammonia removal. During spring and summer, HROP A was operated with an HRT of $7 \mathrm{~d}$, while HRT in HROP $B$ was 4 to $5 \mathrm{~d}$. During autumn and winter, HROP A was operated with an HRT of $10 \mathrm{~d}$, while in HROP B it was $8 \mathrm{~d}$. Nevertheless, during March and several days of April 1994, it was necessary to increase the HRT of HROP B in order to reduce the concentration of suspended solids in the effluent and to ensure secondary treatment. In July 1994, HRT was reduced to $4 \mathrm{~d}$ in HROP A and $3 \mathrm{~d}$ in B in order to check performance at low HRT. The combination of the HRT adopted in each HROP gives six operation periods in which the HROPs operated in parallel with different HRT (except March 1994) but with the same environmental conditions. The loads applied ranged between 8.2 to $28 \mathrm{~g} \mathrm{COD} / \mathrm{m}^{2} \cdot \mathrm{d}, 1.6$ to $5.2 \mathrm{~g} \mathrm{~N} / \mathrm{m}^{2} \cdot \mathrm{d}$ and 0.3 to $0.9 \mathrm{~g} \mathrm{P} / \mathrm{m}^{2} \cdot \mathrm{d}$, and fell within the ranges usually used in these types of ponds (Metcalf and Eddy, 1991). The surfaceloading rate of the secondary clarifiers ranged from 2 to $6 \mathrm{~m}^{3} / \mathrm{m}^{2} \cdot \mathrm{d}$, according to the HRT applied to the HROP.

Grab samples of the HROP influent (effluent of the storage tank), mixed liquor and effluent of the clarifiers were taken weekly, always at midday.

Dissolved reactive phosphorus (DRP), which is largely a measure of orthophosphate (StandardMethods, 1995), was analysed from filtered samples. Total phosphorus (TP) was analysed from 
raw samples using the persulfate oxidation technique: the organically-bound phosphates and polyphosphates are converted to DRP after digestion, which is analysed together with the DRP. Dissolved phosphorus (DP) was analysed from filtered samples in the same way as TP. The difference between DP and DRP makes it possible to estimate the sum of dissolved organically-bound phosphates and dissolved hydrolyzable phosphates, which we have called dissolved organic and hydrolyzable phosphorus (DOHP). Particulate phosphorus (PP), which includes particulate organically-bound phosphates, particulate hydrolyzable phosphates and DRP associated with particles, was determined by the difference between TP and DP. pH was measured with a Crison Portable $506 \mathrm{pH}-$ meter.

Phytoplankton biomass was estimated by spectrophotometric quantification of chlorophyll $a$ with $90 \%$ acetone extraction after $24 \mathrm{~h}$, at $5^{\circ} \mathrm{C}$ in darkness (Jeffrey and Humphrey, 1975). The phytoplankton composition was studied with a Nikon 104 microscope with phase contrast.

Solar radiation measurements were provided by a nearby meteorological station. Water temperature was measured in the mixed liquor of both HROPs.

The flow pattern of the experimental HROPs was previously evaluated with fluorescein tracer. The HROPs behaved almost as perfect complete-mix reactors within the range of HRTs used ( 3 to $10 \mathrm{~d})$. In accordance with this, the following mass balance with respect to DRP concentration for HROP can be applied:

$$
\frac{d(V C)}{d t}=Q_{1} C_{1}-Q_{2} C_{2}-k_{A} A C_{2}
$$

where:

$d(V C) / d t$ is the variation of DRP concentration in time and in the volume reactor, $\mathrm{g} / \mathrm{d}$

$Q_{1}$ and $Q_{2}$ are inflow and outflow respectively, $\mathrm{m}^{3} / \mathrm{d}$

$C_{1}$ and $C_{2}$ are influent and mixed liquor DRP concentrations, $\mathrm{g} / \mathrm{m}^{3}$

$k_{A}$ is the first-order rate constant of DRP removal, $\mathrm{m} / \mathrm{d}$

$A$ is the surface of the HROPs, $\mathrm{m}^{2}$.

Assuming:

- the HROP reaches the steady state: $\frac{d(V C)}{d t}=0$

- inflow and outflow are the same: $Q_{1}=Q_{2}$

- $C_{1}$ can be considered TP because the decomposition or hydrolysis of PP and DOHP from the influent to DRP in the HROP are almost completed due to the high HRT of the ponds (Nurdogan and Oswald, 1995).

Equation (1) makes it possible to estimate the observed values of $k_{A}$ by means of:

$$
k_{A}=\frac{Q_{1}}{A}\left(\frac{C_{1}}{C_{2}}-1\right)
$$

The observed values of $k_{A}$ were used to evaluate the influence of phytoplankton biomass, $\mathrm{pH}$ and the environmental factors on DRP removal. They were calculated employing only data from samples that fulfilled the following requirements:

- number of days above 3HRT after any modification of HRT, and

\section{TABLE 1}

(he influent

\begin{tabular}{|c|c|c|c|c|}
\hline er & $n$ & average & deviation & range \\
\hline & 51 & 7.68 & 2.6 & $7.18-8.13$ \\
\hline vity, $\mu \mathrm{S} / \mathrm{cm}$ & 54 & 1930 & 260 & $1550-2480$ \\
\hline d solids, $\mathrm{mg} / \mathrm{l}$ & 58 & 49 & 17 & $8-90$ \\
\hline $\mathrm{O}_{2} / \ell$ & 56 & 270 & 62 & $110-450$ \\
\hline $\mathrm{mg} \mathrm{N}^{2} \mathrm{l}$ & 55 & 51.2 & 14.2 & $18.3-75.5$ \\
\hline us, $\mathrm{mg} \mathrm{P} / \ell$ & 57 & 8.50 & 1.86 & $3.57-13.05$ \\
\hline
\end{tabular}
$n$ is the number of data used for the calculations and outflow.

Weekly cumulative outflow was calculated taking into account cumulative evaporation and rainfall.

As intermediate correlations were suspected between $\mathrm{pH}$, phytoplankton biomass and the $k_{A}$ from HROP B, the structure of the relationship between these three variables was evaluated with the statistical procedure proposed by Legendre and Troussellier (1988). This procedure makes it possible to detect spurious correlations between variables. Firstly, the possible interaction models between the variables are established. Secondly, the predictions derived from each interaction model are verified with the Mantel random test. The model with all of its predictions made - and only this model - cannot be rejected. The Mantel test between two variables uses a distance matrix for each variable, from which the correlation is calculated by means of the Mantel statistic. In this study, these matrices were obtained from the differences (in absolute value) between all possible pairs of data of each variable. The Mantel statistic is calculated as the sum of the cross-products of the corresponding values in the two matrices $\left(Z=\Sigma \Sigma x_{i j} y_{i j}\right)$. After that, the Mantel statistic is tested for significance of independence (no correlation between the variables). The significance in this study was determined by randomly permuting 100 times the order of the elements of one of the two distance matrices and calculating the Mantel statistic each time. If the variables are not correlated, any random permutation must have a Mantel statistic value equal to or higher than that observed in the real sequence (null hypothesis). When less than 5 of the 100 permutations have Mantel statistic values equal to or higher than that observed in the real sequence, it is considered that the variables are correlated (alternative hypothesis). The Mantel test between three distance matrices (A.B).C, each one derived from a variable, is the partial Mantel test of the values of $\mathrm{A}$ and $\mathrm{B}$, conditioned by the values of $\mathrm{C}$ (the residuals of the linear regression of $\mathrm{A}$ and $\mathrm{C}$, and $\mathrm{B}$ and $\mathrm{C}$ are used for the calculation of the distance matrices). All of the calculation procedures associated with the Mantel test were carried out with the statistical package R (Legendre and Vaudor, 1991).

\section{Results and discussion}

Table 2 shows the average concentration of TP, PP, DOHP and DRP during the overall study in the influent, the mixed liquor and the effluent. TP concentration in the mixed liquor of both HROP was higher than in the influent due to accumulation because the estimated total loss of water by evaporation $(1380 \mathrm{~mm})$ was higher than rainfall measurements $(540 \mathrm{~mm})$. Average TP removal was higher in HROP A $(43 \%)$ than in B $(32 \%)$ in accordance to the higher HRT used in HROP A. 
TABLE 2

Average concentration of TP and the phosphorus species ( $\mathrm{mg} \mathrm{P} / \ell$ ) in the influent, the mixed liquor and the effluent of both HROP. $n=57$.

\begin{tabular}{|l|c|c|c|c|}
\hline HROP & Parameter & Influent & Mixed liquor & Effluent \\
\hline A & TP & 8.50 & 9.95 & 4.82 \\
& PP & 1.15 & 7.14 & 1.28 \\
& DOHP & 0.63 & 0.62 & 0.49 \\
& DRP & 6.77 & 2.19 & 3.05 \\
B & TP & 8.50 & 9.69 & 5.77 \\
& PP & 1.15 & 6.02 & 1.65 \\
& DOHP & 0.63 & 0.67 & 0.35 \\
& DRP & 6.77 & 3.00 & 3.77 \\
\hline
\end{tabular}

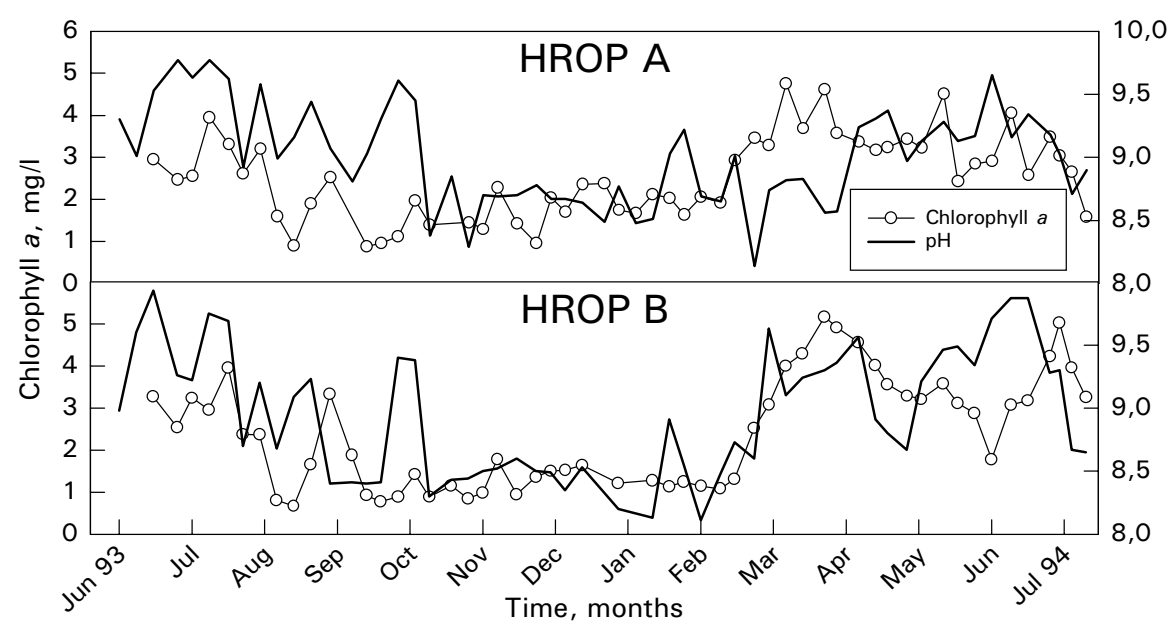

Figure 3

Dynamics of the phytoplankton biomass and $\mathrm{pH}$ in the mixed liquor of both HROPs throughout the study

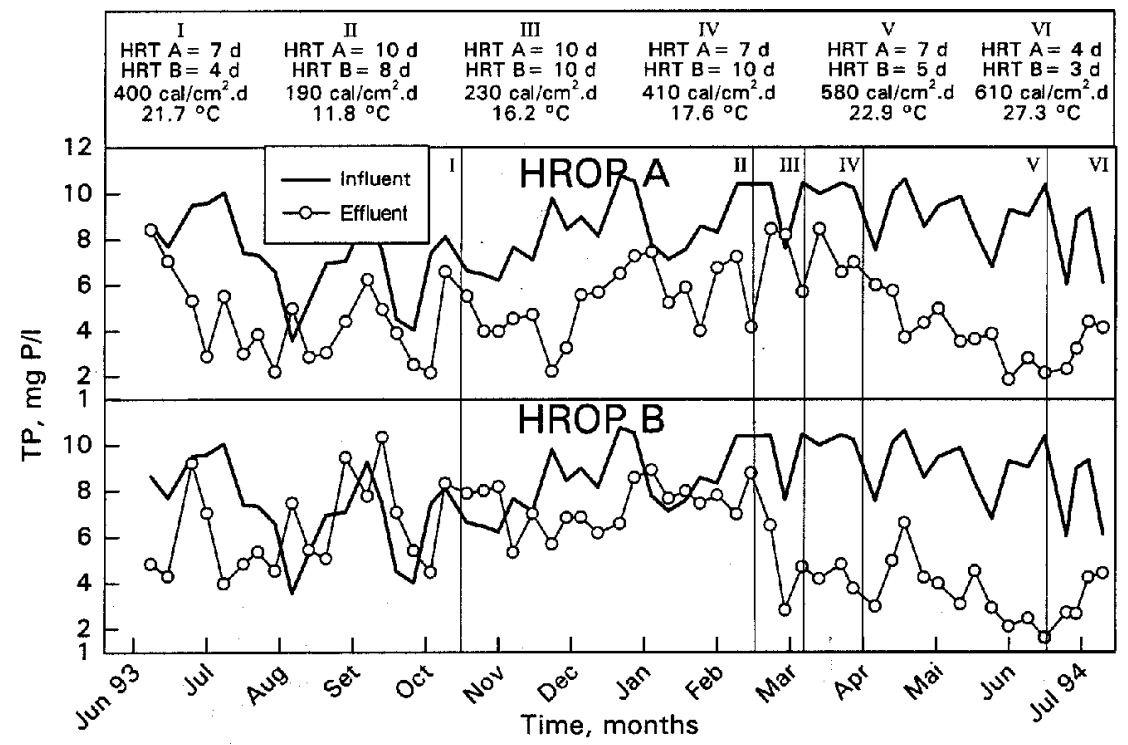

Figure 4

Dynamics of the TP concentration in the influent and the effluent of both HROPS throughout the study. Also shown are the HRT, mean solar radiation and temperature of each operation period (Roman numerals).
The average proportion of phosphorus species during the overall study varied between influent, mixed liquor and effluent. DRP concentration was higher in the influent (80\%) than in the mixed liquor $(22 \%$ in HROP A and $31 \%$ in B), while PP concentration was higher in the mixed liquor $(72 \%$ in HROP A and $62 \%$ in B) than in the influent (14\%). These results are related to phytoplankton metabolic activity, which reduces DRP and increases PP in the mixed liquor by incorporating DRP in the algal cells (by chemical precipitation onto the cell walls and by uptake). The average proportion of DOHP was similar in the influent (7\%) and in the mixed liquor (6\% in HROP A and $7 \%$ in B). DRP was the most important phosphorus species in the effluent (63\% in HROP $\mathrm{A}$ and $65 \%$ in B) due to PP sedimentation in the clarifier. The slightly higher DRP concentration in the effluent of both HROP than in the mixed liquor was due to respiration of algal biomass settled in the clarifier, which resulted in a $\mathrm{pH}$ reduction that promoted redissolution of PP as DRP. As is shown in Table 2, there is little difference between influent and effluent PP values. However, it should be taken into account that influent PP is related to fine particulate organic matter and bacteria, while effluent PP is related to algal cells that escaped 동 from the clarifiers.

Figure 3 shows the evolution of phytoplankton biomass and $\mathrm{pH}$ in the mixed liquor of both HROPs for the entire period of study. Chlorophyll $a$ concentration and $\mathrm{pH}$ had a prevailing seasonal trend in both HROPs, with higher values in spring and summer, and lower values in autumn and winter. Figure 4 shows the temporal evolution of TP concentration in the influent and the effluent of both HROPs; HRT, mean solar radiation and temperature for each operation period are also shown. Figure 5 shows the evolution of the phosphorus species in the effluent of both HROPs. In operation period I, TP effluent concentration was normally higher in HROP B than in A, especially at the end of the period. These higher values were related to a clearly higher DRP concentration in HROP B in September and October. In fact, during a part of these months, HROP B had a slightly higher effluent TP concentration than that observed in the influent. This could be due to phosphorus accumulation as a result of water losses by evaporation or/and by underestimation of influent $\mathrm{TP}$ because influent values were only representative of one daily grab sample, while effluent was representative of several days influent. In all the instances, these results indicate that HROP B did not remove phosphorus in those months. The DRP concentration increases at the end of this period in the effluents of both 
HROPs were related to the seasonal lowering of solar radiation and temperature, which, in turn, caused a decrease in the mixed liquor phytoplankton biomass concentration and in the $\mathrm{pH}$ (especially in HROP B). In operation period II, TP effluent concentration was lower in HROP A than in $\mathrm{B}$ throughout. This trend was also related to the fact that DRP concentration in HROP B was higher than in A. The decrease in solar radiation and temperature in this period (autumn and winter) gave as a result the lowest phytoplankton biomass concentration and $\mathrm{pH}$ observed during the overall study, which, in turn, produced the highest DRP concentration observed in both HROPs. During operation period III, TP effluent concentration was lower in HROP $B$ than in A, also in connection with a lower DRP concentration. This result seems to be rather illogical, because the two HROPs operated in this period with the same HRT. However, it can be attributed to the effect of increasing the HRT in HROP B from period II to III, which resulted in a drastic increase in phytoplankton biomass concentration and $\mathrm{pH}$ in connection with the higher solar radiation and temperature observed at the beginning of spring. TP and DRP effluent concentration was lower in HROP B in operation

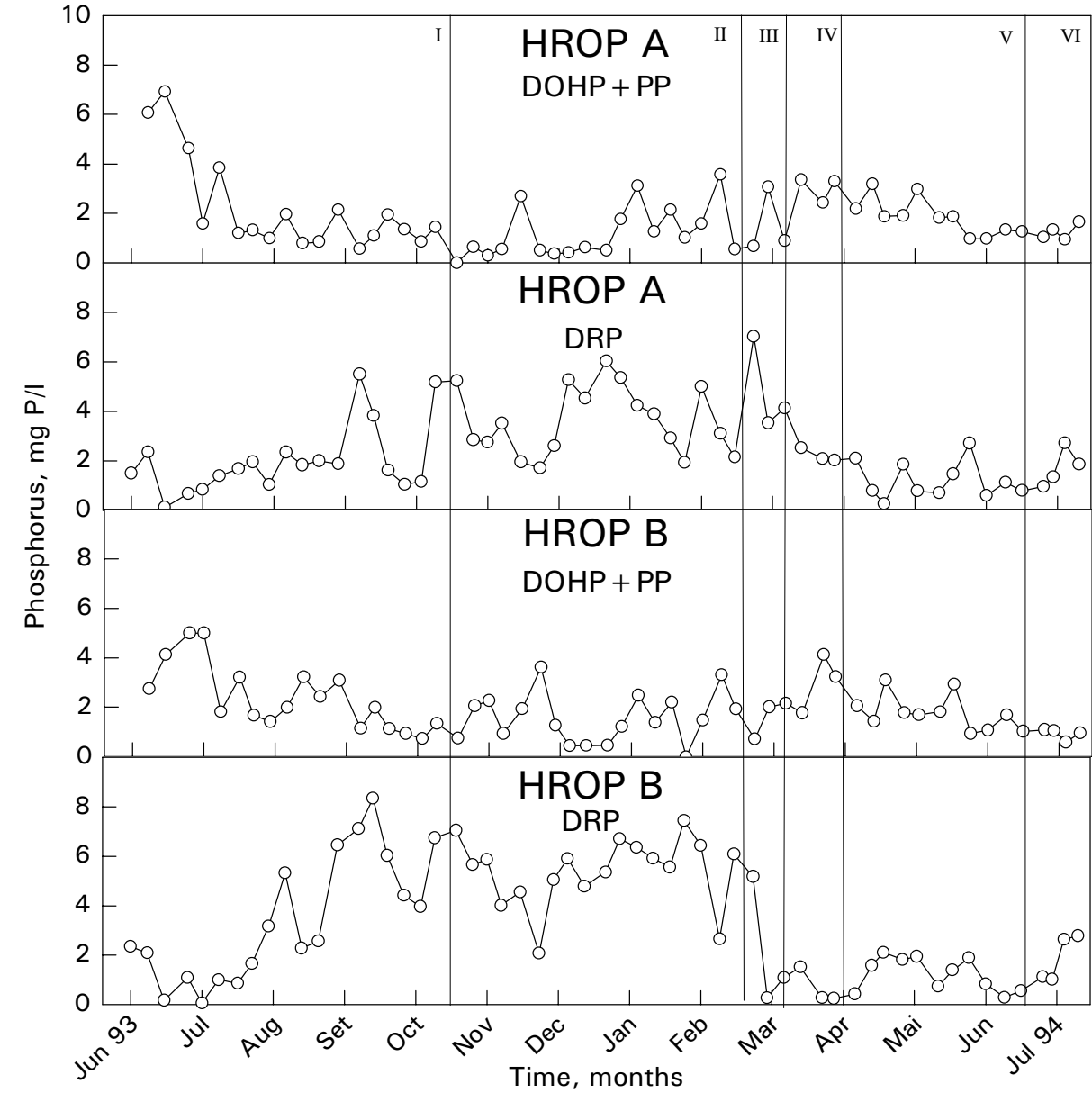

Figure 5

Evolution of the phosphorus species in the effluent of both HROPs throughout the year. Also shown are the operation periods (Roman numerals).

period IV. Within this period, $\mathrm{pH}$ was

clearly higher in HROP B than in A, while phytoplankton biomass concentration was similar. In operation period V, both HROPs attained a similar TPeffluent concentration and the highest phosphorus removals during the overall study were observed here. This is one of the three larger operation periods (I, II and V) with the highest solar radiation and temperature which resulted in a high phytoplankton biomass concentration and $\mathrm{pH}$. In the last operation period, high TP removals were also observed in both HROPs. However, effluent TP (and DRP) concentration increased at the same time as phytoplankton biomass, and $\mathrm{pH}$ tended to reduce as a result of the low HRT used in both HROPs.

Figure 5 shows that the sum of DOHP and PP concentrations had a similar temporary evolution in the two HROPs, mainly in relation to PP variations because PP concentration was clearly higher than DOHP concentration (see Table 2). The highest values of the sum of DOHP and PP were observed in both HROPs at the beginning of the study and during spring, when the phytoplankton was dominated by the algae Dictyosphaerium pulchellum and Scenedesmus acutus. These green algae were present in the mixed liquor as discrete non-flocked particles and did not settle in the clarifiers, raising the PP

\begin{tabular}{|c|c|c|c|c|}
\hline \multicolumn{5}{|c|}{$\begin{array}{c}\text { TABLE } 3 \\
\text { Average and standard deviation of DRP concentration (mg P/ } / \text { ) in } \\
\text { the mixed liquor for each operation period. The mean values of } \\
\text { chlorophyll } a(\mathrm{mg} / \ell) \text { followed by the pH are shown in parentheses. } \\
\text { The results of the ANOVA from the comparison of the DRP } \\
\text { averages are also shown. }\end{array}$} \\
\hline & Period I & Period II & Period V & Period VI \\
\hline HROP A & $\begin{array}{l}1.75 \pm 1.32 \\
(1.7 / 9.0)\end{array}$ & $\begin{array}{l}3.01 \pm 1.13 \\
(1.9 / 8.8)\end{array}$ & $\begin{array}{l}0.74 \pm 0.38 \\
(3.1 / 9.4)\end{array}$ & $\begin{array}{l}1.33 \pm 0.60 \\
(2.7 / 9.1)\end{array}$ \\
\hline HROP B & $\begin{array}{l}2.40 \pm 2.24 \\
(1.4 / 8.9)\end{array}$ & $\begin{array}{c}5.09 \pm 1.33 \\
(1.3 / 8.6)\end{array}$ & $\begin{array}{l}0.99 \pm 0.61 \\
(3.5 / 9.2)\end{array}$ & $\begin{array}{c}1.44 \pm 0.87 \\
(3.9 / 9.0)\end{array}$ \\
\hline ANOVA & $P=0.51605\left(^{*}\right)$ & $P=0.00007(\mathrm{~N})$ & $P=0.35145\left(^{*}\right)$ & $P=0.86874\left(^{*}\right)$ \\
\hline \multicolumn{5}{|c|}{$\begin{array}{l}\text { (*) Averages are equal at the level of significance } \alpha=0.05 \text {. } \\
\text { (N) Averages are not equal. }\end{array}$} \\
\hline
\end{tabular}


concentration of the effluent. During those periods the sum of DOHP and PP concentrations was higher than DRP concentration in both HROPs. DRP concentration in both HROPs had a prevailing seasonal trend opposite to that observed for phytoplankton biomass and $\mathrm{pH}$, with higher values in autumn and winter. Although for a large part of these seasons both HROPs operated with the higher HRT during the overall study, it was not enough to reduce DRP concentration to a similar level as the rest of the time. This result

\begin{tabular}{|c|c|c|}
\hline \multicolumn{3}{|c|}{$\begin{array}{c}\text { TABLE } 4 \\
\text { Pearson linear correlations and associated } \\
\text { probabilities between the natural logarithm of } k_{A} \text { and: } \\
\text { solar radiation, temperature, phytoplankton biomass } \\
\text { and pH in the mixed liquor }\end{array}$} \\
\hline & In $k_{A}$, HROP A & In $k_{A}$, HROP B \\
\hline Solar radiation & $\begin{array}{c}0.749 \\
P=0.00000(*)\end{array}$ & $\begin{array}{c}0.812 \\
P=0.00000(*)\end{array}$ \\
\hline Temperature & $\begin{array}{c}0.781 \\
P=0.00000(*)\end{array}$ & $\begin{array}{c}0.789 \\
P=0.00000(*)\end{array}$ \\
\hline $\begin{array}{l}\text { Phytoplankton } \\
\text { biomass }\end{array}$ & $\begin{array}{c}0.173 \\
P=1.00000(\mathrm{~N})\end{array}$ & $\begin{array}{c}0.682 \\
P=0.00005(*)\end{array}$ \\
\hline $\mathrm{pH}$ & $\begin{array}{c}0.758 \\
P=0.00000(*)\end{array}$ & $\begin{array}{c}0.755 \\
P=0.00000(*)\end{array}$ \\
\hline \multicolumn{3}{|c|}{$\begin{array}{l}\text { (*) Correlation is significant at the Bonferroni level of significance } \\
\alpha=0.05 \text { for each test. } \\
\text { (N) Test is not significant. }\end{array}$} \\
\hline
\end{tabular}

manifested the importance of solar radiation and temperature as indirect control factors for DRP removal through its influence on phytoplankton biomass concentration and, in turn, on $\mathrm{pH}$.

\section{Influence of HRT on DRP removal in the mixed liquor}

The methodology used makes it possible to compare the influence of HRT on DRP concentration, because the two HROPs were operated under the same environmental conditions. Table 3 shows the average concentration of DRP, chlorophyll $a$ and $\mathrm{pH}$ in the mixed liquor of both HROPs for each operation period, and the results of the ANOVA from the comparison of the DRP averages. Periods III and IV were not considered in this analysis because they were very short and only very few data fulfilled the two requirements stated in the Experimental section. As can be observed, the higher HRT used in HROP A caused a lower average mixed liquor DRP concentration in all of these periods. However, the ANOVA method indicates that only operation period II (which contained data mainly from autumn and winter) had a significantly different DRP concentration. This result shows that the HRT influence is more important during periods with low solar radiation and temperature. The $\mathrm{pH}$ was systematically higher in HROP A than in $\mathrm{B}$ for all of the periods, while the phytoplankton biomass did not follow this trend.

\section{Influence of phytoplankton biomass, $\mathrm{pH}$ and environmental factors on DRP removal in the mixed liquor}

Table 4 shows the Pearson linear correlation between the natural logarithm of $k_{A}$ and solar radiation, water temperature, phytoplankton biomass and $\mathrm{pH}$. Correlations were positive, high and significant, except for phytoplankton biomass in HROP A. These results

\begin{tabular}{|c|c|c|c|c|c|c|}
\hline & Model & $\begin{array}{c}\text { Predictions } \\
\text { of model }\end{array}$ & $\begin{array}{l}\text { om puted } \\
\text { results }\end{array}$ & Model & $\begin{array}{l}\text { Predictions } \\
\text { of model }\end{array}$ & $\begin{array}{l}\text { Com puted } \\
\text { results }\end{array}$ \\
\hline I. & $\begin{array}{c}\text { Biomass } \\
\begin{array}{c}1=\text { Biomass } \\
2=\mathrm{pH} \\
3=\ln k_{\mathrm{A}}\end{array}\end{array}$ & $\begin{array}{l}1.3 \neq 0 \\
2.3 \neq 0 \\
1.2=0 \\
(1.2) .3 \neq 0 \\
(2.3) .1 \neq 0 \\
(1.3) .2=0 \\
(1.3) .2 \geqslant 1.3 \\
(2.3) .1 \geqslant 2.3\end{array}$ & $\begin{array}{l}\text { yes } \\
\text { yes } \\
\text { no } \\
\text { yes } \\
\text { no } \\
\text { yes } \\
\text { no } \\
\text { no }\end{array}$ & II. Biomass & $\begin{array}{l}1.2=0 \\
1.3 \neq 0 \\
2.3=0 \\
(1.2) .3=0 \\
(1.3) .2=0 \\
(2.3) .1=0 \\
(1.3) .2 \leqslant 1.3 \\
(1.2) .3 \leqslant 1.2 \\
(1.2) \times(1.3)=2.3\end{array}$ & $\begin{array}{c}\text { yes } \\
\text { yes } \\
\text { no } \\
\text { yes } \\
\text { no } \\
\text { no } \\
\text { yes } \\
\text { yes } \\
\text { no }\end{array}$ \\
\hline III. & $\begin{array}{l}\text { Biomass } \\
\begin{array}{l}1=\mathrm{Biom} \text { ass } \\
2=\mathrm{pH} \\
3=\operatorname{In} k_{\mathrm{A}}\end{array}\end{array}$ & $\begin{array}{l}1.2 \neq 0 \\
2.3 \neq 0 \\
1.2 \geqslant 1.3 \\
2.3 \geqslant 1.3 \\
(1.3) .2=0 \\
(1.2) .3 \neq 0 \\
(2.3) .1 \neq 0 \\
(1.2) .3 \leqslant 1.2 \\
(2.3) .1 \leqslant 2.3 \\
(1.2) \times(2.3)=(1.3)\end{array}$ & $\begin{array}{l}\text { yes } \\
\text { yes } \\
\text { yes } \\
\text { yes } \\
\text { yes } \\
\text { yes } \\
\text { yes } \\
\text { yes } \\
\text { yes } \\
\text { yes }\end{array}$ & IV. Biomass & $\begin{array}{l}1.2 \neq 0 \\
1 \cdot 3 \neq 0 \\
2.3 \neq 0 \\
(1.2) \cdot 3=0 \\
(1.3) \cdot 2=0 \\
(2.3) \cdot 1 \neq 0\end{array}$ & $\begin{array}{l}\text { yes } \\
\text { yes } \\
\text { yes } \\
\text { yes } \\
\text { no } \\
\text { yes }\end{array}$ \\
\hline
\end{tabular}

Figure 6

Interaction models between phytoplankton biomass, $\mathrm{pH}$ and natural logarithm of $\mathrm{k}_{\mathrm{A}}$ in HROP B. Also shown are the predictions and the results of the Mantel test applied to the predictions. 
indicate that DRP removal in both HROPs was greatly influenced by seasonal changes in solar radiation and temperature. The effect of these environmental factors on DRP removal is indirect through their influence on both phytoplankton biomass and $\mathrm{pH}$. However, in HROP A, pH was correlated with $\ln k_{\mathrm{A}}$ while phytoplankton biomass was not, suggesting that chemical precipitation was the principal direct process for phosphorus removal. In HROP B, both phytoplankton biomass and $\mathrm{pH}$ were correlated with $\ln k_{A}$. Also in this HROP, phytoplankton biomass and $\mathrm{pH}$ were correlated (0.620), while they were not in HROP A (0.184). Consequently, and taking into account the results obtained in HROP A, it was suspected that the correlation between phytoplankton and $\ln k_{A}$ in HROP B might be spurious and due to their common correlation to $\mathrm{pH}$. The procedure of Legendre and Troussellier (1988) was used to evaluate the structure of the relationship between these three variables in HROP B. Figure 6 shows the four possible interaction models between the variables, the predictions of each model and the computed results for the verification of the predictions with the Mantel test. When a prediction is not zero, this means that the variables involved are correlated. For example, in model III the first prediction indicates that phytoplankton biomass (1) is correlated with $\mathrm{pH}$ (2). The Mantel test confirms this prediction ("yes" in the computed results column). As another example, (1.2).3 $\leq 1.2$ in model III means that the Mantel statistic calculated between phytoplankton biomass residuals and $\mathrm{pH}$ residuals (the residuals were obtained from the linear regression of $\ln k_{A}$ and phytoplankton biomass, and from $\ln k_{A}$ and $\mathrm{pH}$ ) is lower than the Mantel statistic calculated between phytoplankton biomass and $\mathrm{pH}$ directly. This prediction was confirmed by the data and appears as "yes" in the computed results column. As can be observed, models I, II and IV are not supported by the data, because one or several predictions are not made. All ten predictions of model III are made, and as a result this model - and this model only - cannot be rejected. This model confirms that the positive and significant Pearson correlation between phytoplankton and $\ln k_{A}$ was due to their common correlation to $\mathrm{pH}$. The conclusion is that in HROP B pH and $\ln k_{\mathrm{A}}$ are directly correlated, while phytoplankton biomass and $\ln k_{A}$ are not, suggesting that chemical precipitation was also the principal direct process for phosphorus removal in this HROP.

\section{PP removal in the secondary clarifier}

TP removal in the experimental system tested occurs by DRP removal in the mixed liquor as a result of their transformation to PP and subsequent PP removal in the clarifiers. It was observed that mixed liquor PP was positively correlated with phytoplankton biomass ( 0.728 for HROP A and 0.703 for B), and PP removal was related to the clarifiers' phytoplankton biomass separation efficiency. PP mixed liquor average removal efficiency was higher in HROP A $(82 \%)$ than in B (73\%) since the effluent had a very similar PP concentration, while mixed liquor PP was present at a higher concentration in HROP A (see Table 2). The absence of clarifiers in this study would not have allowed TP removal because TP average concentration in the mixed liquor of both HROPs was higher than that observed in the influent. Other workers (El Halouani, 1990; Mesplé et al., 1995) have recorded TP removal in the mixed liquor and have related this phenomenon to chemical precipitation of orthophosphate. In these studies, as may be assumed that a small fraction of the phytoplankton settled at the bottom of the HROP, while chemical precipitation occurs on the algal cell walls (Sukenik et al., 1985).

\section{Conclusions}

- Phosphorus removal in HROPs operated to reach secondary treatment standards is partly controlled by the HRT through its influence on DRP removal in the mixed liquor. HRT influence is more important during periods with low solar radiation and temperature (autumn and winter) because DRP removal is also affected by these environmental factors. Although both HROPs operated in autumn and winter with the highest HRT of all of the study period, DRP mixed liquor concentration observed in these seasons was the highest. This indicates that the lowering of solar radiation and temperature is barely compensated by the increase of HRT, at least in a practical range of HRT to achieve secondary treatment standards.

- The principal mechanism of phosphorus removal in an HROP with a clarifier is the incorporation of DRP into the phytoplankton biomass in the mixed liquor as PP (as a chemical precipitate on the cell wall), followed by PP separation in the clarifier. The critical point of the mechanism is DRP incorporation, which depends on solar radiation, temperature and HRT though their influence on $\mathrm{pH}$ and chemical precipitation. Phytoplankton uptake appears to be a minor process for DRP removal in comparison to chemical precipitation.

\section{Acknowledgements}

The detailed technical review conducted by OV Shiping is acknowledged gratefully. This study was supported by the DGICYT of the Spanish Department of Education and Science, project number PB-92-0535.

\section{References}

ABELIOVICH A (1986) Algae in wastewater oxidation ponds. In: Richmond A (ed.) Handbook of Microalgal Mass Culture. CRC Press, Boca Ratón. 331-338.

CROMAR NJ, FALLOWFIELD HJ and MARTIN NJ (1996) Influence of environmental parameters on biomass production and nutrient removal in a high rate algal pond operated by continuous culture. Water Sci. Technol. 34 (11) 133-140.

EL HALOUANI H (1990) Lagunage à Haut Rendement: Caractérisation Physic-Chimique del'Ecosystème, Étude de son Aptitudeàl'Élimination de l'Azote et du Phosphore dans l'Épuration des Eaux Usées. Thèse de doctorat, Université de Montpellier I. 154 pp.

FALLOWFIELD HJ and GARRET MK (1985) The treatment of wastes by algal culture. In: Brown CM and White WR (eds.) Microbial Aspects of Water Management. Society for Applied Bacteriology Symposium. 14. Academic Press, London. 187-205.

JEFFREY SW and HUMPHREY GF (1975) New spectrophotometric equations for determining chlorophylls $a, b, c 1$ and $c 2$ in higher plants, algae and natural phytoplankton. Biochem. Physiol. Pflanzen 167 191-194.

LEGENDRE P and TROUSSELLIER M (1988) Aquatic heterotrophic bacteria: Modeling in the presence of spatial autocorrelation. Limnol. Oceanogr. 33 (5) 1055-1067.

LEGENDRE P and VAUDOR A (1991) The R Package: Multidimensional Analysis, Spatial Analysis. Département de Sciences Biologiques, Univ. de Montreal. $142 \mathrm{pp}$.

MESPLÉ F, TROUSSELLIER M, CASELLAS C and BONTOUX J (1995) Difficulties in modeling phosphate evolution in a high rate algal pond. Water. Sci. Technol. 31 (12) 45-54.

METCALF ANDEDDY INC. (1991) Wastewater Engineering. Treatment, Disposal and Reuse (3rd edn.) McGraw-Hill, New York. 1334 pp.

MOUTIN T, GAL JY, EL HALOUANI H, PICOT B and BONTOUX J (1992) Decrease of phosphate concentration in a high rate pond by precipitation of calcium phosphate: Theoretical and experimental results. Water Res. 26 (11) 1445-1450. 
NURDOGAN Y and OSWALD WJ (1995) Enhanced nutrient removal in high-rate ponds. Water Sci. Technol. 31 (12) 33-44.

OSWALD WJ (1988a) The role of microalgae in liquid waste treatment and reclamation. In: Lembi CA and Waaland JR (eds.) Algae and Human Affairs. Cambridge Univ. Press, Cambridge. 255-282.

OSWALD WJ (1988b) Micro-algae and waste-water treatment. In: Borowitzka MA and Borowitzka LJ (eds.) Micro-algal Biotechnology. Cambridge Univ. Press, Cambridge. 304-328.

OSWALD WJ and GOTAAS HB (1957) Photosynthesis in sewage treatment. Trans. Am. Soc. Civ. Eng. 122 73-105.
PICOT B, EL HALOUANI H, CASELLAS C, MOERSIDIK S and BONTOUX J (1991) Nutrient removal by high rate pond system in a Mediterranean climate. Water Sci. Technol. 23 1535-1541.

SHELEF G, MORAINE R and ORON G (1982) Nutrients removal and recovery in a two-stage high rate algal wastewater treatment system. Water Sci. Technol. 14 87-100.

STANDARD METHODS (1995) Standard Methods for the Examination of Water and Wastewater (19th edn.), American Public Health Association, Washington, DC.

SUKENIK A, SCHRÖDER W, LAUER J, SHELEF G and SOEDER CJ (1985) Coprecipitation of microalgal biomass with calcium and phosphate ions. Water Res. 19 (1) 127-129. 